\section{Crossing of Two Allopatric Populations of Culex fatigans Wiedemann}

Two colonies of Culex fatigans are maintained in the insectary: one from Lagos, the other from British Guiana (obtained through the kindness of Dr. I. J. Charlos). The two strains were subject to a preliminary taxonomic examination and to experimental crossing.

There was no difference in the morphology of adults or pupæ of the two strains. There was no constant difference in the morphology of the 4th instar larvæ except for the presence of black tips on the anal papillæ of larvæ from British Guiana. Larvæ of both strains had the same survival threshold $(9 / 1,000)$ when subjected to a salinity test with sodium chloride.

Two colonies were set up : British Guiana males with Lagos females and British Guiana females with Lagos males. 'The resulting generations were about equal in number. The $F_{1}$ generation from British Guiana mothers showed black-tipped anal papillæ in 80.0 per cent of examined larvæ. None of the $F_{1}$ generation derived from Lagos females possessed this character. Both these populations were selfed. The $F_{2}$ generation from British Guiana females had 100 per cent frequency of black-tipped anal papillæ, while none of the other $F_{2}$ generation possessed this character. On further selfing this character disappeared, however, and remained absent in further generations.

The two populations of $C$. fatigans are conspecific judging from the ease with which fertile hybrids were produced. There are, to our knowledge, no other records of experimental crossing of two allopatric populations of $C$. fatigans.

$$
\begin{gathered}
\text { Federal Malaria Service, } \\
\text { Yaba-Lagos, Nigeria. }
\end{gathered}
$$$$
\text { Aug. } 2 .
$$

M. W. Service

\section{Pugnacity of Marlins and Swordfish}

From a wido area of the sea there have been reported occasional incidents illustrating the pugnacity of marlins and swordfish. This has been supported by recent evidence from South African seas, as a result of the Second World War, whon a number of ships from the East were torpedoed in the Mozambique Channel. From these vessels quantities of bales of rubber were left floating awash, and from that time many thousands have continually been stranded, over an enormous stretch of the coast of South and East Africa. A good many bales must have remained in eddies, since even to-day they continue to come ashore. It was soon noticed that many bales contained the tips of spears of marlins, and it now appoars that the longer a bale remains in the sea the more broken spears it is likely to contain, for those cast ashore in recent times have held as many as four. Most of these residues have been the tips broken near the front of the spear.

Marlin must deliberately charge floating or submerged objects, intending to impale them, possibly to secure food, but possibly also from plain aggressiveness. Almost all the spear tips found have been small, indicating marlins of 5-8 ft. in length, most found 4-6 in. within the bale, indicating very considerable penetrative force. This might suggest that small marlins are more aggressive than larger fishes; but it may equally be argued that the very much more densely ossified stout spear of the large fish would be less likely to break at any point, so that larger fish would have more hope of withdrawal. That large marlins also have this habit is indicated clearly by a bale recently found, in which was found embedded, to a dopth of 13 in., virtually immovable, the apical $24 \mathrm{in}$. of the stout spear of a black marlin that could not have been less than $11 \mathrm{ft}$. in length with a weight of probably $400 \mathrm{lb}$. It is clear that to drive so stout a spear into a floating bale of resistant rubber so deeply, the fish must have been moving at great speed. It is equally clear that it must have taken very great force to break so stout a spear near its base in the skull, and the clue to what had happened was furnished by somo teeth of a large shark (probably Carcharinus) also found embedded in the same bale. This marlin paid dearly for its pugnacity. Hampered by the heavy bale in that position, it would neither be able to withdraw the spear nor break so stout a bony rod. Its struggles must soon have attracted sharks, abundant in Last African seas, that in increasing numbers would rapidly have torn it to pieces and become blood crazed in the process. In the mêlée one of them must have seized the bale of rubber and it was doubtless this that provided the extra force needed to fracture the stout spear. It was from this chance that the bale in question still retained sufficient buoyancy to reach the shore. In most such cases the weight of the severed head or of the skull of a large marlin would cause the bale to sink.

In one bale was also found the undoubted sword of the broadbill swordfish (Xiphias), indicating a similar habit for that species.

It was from this evidence that I had earlier come to believe that marlin were abundant in south-east African seas, as has been amply proved in recent times.

\section{Rhodes University, Grahamstown.} Aug. 10 .

\section{J. L. B. SMIth}

\section{Light Energy and Brightness Sensation}

ENGINELRING problems demand a knowledge of the relation between onergy stimulus and the resulting sensation. In the field of acoustics, scales of 'loudness' have been derived which aro of engineering value.

In the field of lighting and vision, the derivation of scales of apparent brightness is made more difficult by the influence of adaptation and simultaneous contrast. Tho sensation which is given by a patch of given luminance (physical brightness) depends not only on the energy emitted from the patch but also on the luminances of the neighbouring parts of the field of view. Abribat ${ }^{1}$ showed how a scale of apparent brightness, which took adaptation into account, could be derived from just noticeablo differences. Data obtained by Pitt ${ }^{2}$ using a binocular matching technique enabled scales of apparent brightness to be drawn up independent of the questionable Fechner integration. Hopkinson ${ }^{3}$ derived a scale of apparent brightness from supra-threshold contrast judgments.

$\Lambda$ new set of determinations of apparent brightness has recently been completed for a limited number of observers, following a discussion with Prof. S. S. 